\title{
Augmentation of the Peripheral Metabolism of L-Triiodothyronine and L-Thyroxine after Acclimation to Cold
}

\author{
MULTIFOCAL STIMULATION OF THE BINDING OF \\ IODOTHYRONINES BY TISSUES
}

\author{
Alan BALSAM with the assistance of LynN E. LePPo \\ From the Biochemical Assessments Branch, Environmental Sciences Division, \\ USAF School of Aerospace Medicine, Brooks Air Force Base, Texas 78235
}

A B S T R A C T Increased metabolism of thyroid hormones was observed in rats adapted to an ambient temperature of $4^{\circ} \mathrm{C}$. The increased hormonal degradation was manifested in enhanced metabolic, urinary deiodinative, biliary, and fecal clearances of iodothyronines. Increased metabolic clearances were due to stimulation of cellular hormonal disposition, evidenced by elevated intrinsic cellular clearances. After adaptation, the concentration of protein-bound iodine in plasma was decreased, and the binding of the hormones by plasma proteins was increased. The enhanced rate of metabolism of iodothyronines was associated with stimulation of the binding of these hormones by diverse tissues, suggesting the participation of extrahepatic degradative foci in the increased hormonal deiodination observed in vivo. Increased hepatocellular binding and a significantly enlarged hepatic distribution space of thyroxine were noted. Hepatocellular binding of triiodothyronine was similarly augmented, and a smaller but significant increase in the hepatic space of this iodothyronine was detected. Analysis of the hepatic subcellular partition of iodothyronines $35 \mathrm{~min}$ after the intravenous administra-

Dr. Balsam's present address is the Department of Medicine, Veterans Administration Hospital, Dallas, Texas 75216.

The research reported in this paper was conducted by personnel of the Environmental Sciences Division, USAF School of Aerospace Medicine, Aerospace Medical Division, AFSC, United States Air Force, Brooks AFB, Texas.

Received for publication 24 July 1973 and in revised form 15 October 1973. tion of isotopically labeled thyroid hormones disclosed increased hormonal binding by the microsomal fraction in cold-adapted animals and an attendant increase in the microsomal protein concentration. Partial microsomal subfractionation in a discontinuous sucrose gradient indicated that the observed stimulation of microsomal hormonal binding was associated with proliferation of the smooth endoplasmic reticulum.

\section{INTRODUCTION}

The detection of substantial concentrations of iodothyronines within exchangeable cellular pools in tissues (1-3) has prompted studies to delineate the location and nature of tissues binding sites associated with the metabolic transformation of thyroid hormones $(4,5)$. Considerable evidence suggests that the hepatic metabolism of iodothyronines is mediated by enzymes residing on the smooth membranous component of hepatic microsomes (6-9). Moreover, after hepatic microsomal induction by specific pharmacological agents, stimulation of hormonal degradation and flux has been observed (10). The importance of extrahepatic degradative sites in hormonal deiodination has been inferred in studies that have demonstrated the presence of significant quantities of iodothyronines in diverse tissues. However, the precise nature of binding sites of thyroid hormones in extrahepatic tissues has not been delineated, nor has the capacity of these sites to be induced by specific stimuli been demonstrated.

In the present series of investigations the peripheral metabolism, tissue binding, and subcellular distribution 
of thyroxine $\left(T_{4}\right)^{1}$ and triiodothyronine $\left(T_{3}\right)$ were evaluated in an effort to obtain further insight into the cellular mechanism involved in the disposition of thyroid hormones after cold acclimation. These studies were based on the conceptual formulations and technological advances in the analysis of hormonal metabolism introduced in the laboratory of Oppenheimer (5, $10,11)$. Increased turnover of $T_{4}$ and increased thyroidal activity after adaptation to the cold have been documented in earlier studies (12-14). However, the role of tissues in the observed stimulation of hormonal turnover has not been defined. Results of the current studies indicate that the cold-induced augmentation in the metabolism of thyroid hormones is associated with stimulation of hepatic and extrahepatic tissue binding of iodothyronines and with the proliferation of degradative subcellular loci within the liver.

\section{METHODS}

Adult male Sprague-Dawley rats ${ }^{2}$ weighing 250-350 g were divided into weight-matched groups and maintained in individual cages at 4 and $25^{\circ} \mathrm{C}$ for periods of 3-5 mo. Animals were supplied a diet of Purina Lab Chow with an iodide content of $1 \mu \mathrm{g}$ per $\mathrm{g}$ of pellet ration and water ad lib. Cold exposure was accompanied by an overall mortality of less than $2 \%$.

Iodothyronines labeled in the phenolic ring with ${ }^{125} \mathrm{I}$ or ${ }^{151}$ I were obtained from Abbott Laboratories, North Chicago, I11. $\mathrm{L}-\left[{ }^{181} \mathrm{I}\right]$ triiodothyronine $\left(\left[{ }^{181} \mathrm{I}\right] \mathrm{T}_{8}\right)$ was diluted in a $1 \%$ human serum albumin (HSA) solution and dialyzed in phosphate buffer for $2 \mathrm{~h}$. L-[ $\left.{ }^{125} \mathrm{I}\right]$ thyroxine $\left(\left[{ }^{125} \mathrm{I}\right] \mathrm{T}_{4}\right)$ was similarly diluted and separately dialyzed for $16 \mathrm{~h}$. Chromatoelectrophoretic analysis of the dialysands revealed less than $0.5 \%$ contamination by radioiodide. The dialyzed preparations were combined, and a preweighed dose containing $10 \mu \mathrm{Ci}\left[{ }^{131} \mathrm{I}\right] \mathrm{T}_{3}$ and $5 \mu \mathrm{CI}\left[{ }^{125} \mathrm{I}\right] \mathrm{T}_{4}$ was injected into the rat tail vein under light ether anesthesia. Hormonal turnover and distribution were measured during a 24-h period after administration of the dose. Serial samples of heparinized blood were obtained from the cut tail vein at $3,6,12$, and $20 \mathrm{~h}$. At $24 \mathrm{~h}$ all animals were exsanguinated through the abdominal aorta. During the turnover study, thyroidal uptake of radioiodide was precluded by preparatory expansion of the iodide pool by subcutaneous injections of $1 \mathrm{mg}$ of $\mathrm{NaI}$ twice daily.

After precipitation of plasma proteins with trichloroacetic

${ }^{1}$ Abbreviations used in this paper: $b_{\mathbf{P}}$, overall strength of binding of undiluted plasma; DF, dialyzable fraction; $\%$ dose, percent of the injected dose; HDS, hepatic distribution space; HSA, human serum albumin; $\left[{ }^{181} \mathrm{I}\right] \mathrm{T}_{3}$, $\mathrm{L}-\left[{ }^{131} \mathrm{I}\right]$ triiodothyronine; $\mathrm{L}-\left[{ }^{225} \mathrm{I}\right]$ thyroxine; $\mathrm{k}$, fractional disappearance rate; $\mathrm{MC}$, metabolic clearance rate; RER, rough endoplasmic reticulum; SER, smooth endoplasmic reticulum; TCA, trichloroacetic acid; TDS, total distribution space; $T_{3}$, triiodothyronine; $T_{4}$, thyroxine.

${ }^{2}$ The animals involved in this study were maintained in accordance with the "Guide for Laboratory Animals Facilities and Care" as published by the National Academy of Sciences, National Research Council. acid (TC.A), plasma specimens ${ }^{8}$ were assayed for radioactivity with a dilution of the injected dose in a dual channel gamma spectrometer. Appropriate correction was made for the appearance of ${ }^{131} \mathrm{I}$ activity in the $35 \mathrm{keV}$ range at which ${ }^{125} \mathrm{I}$ was assayed. All specimens were counted to statistical accuracy $( \pm 2 \%)$ and expressed as a percent of the injected dose ( $\%$ dose). The disappearance curves of plasma [ $\left.{ }^{131} \mathrm{I}\right] \mathrm{T}_{3}$ between 3 and $24 \mathrm{~h}$ and of [ $\left.{ }^{125} \mathrm{I}\right] \mathrm{T}_{4}$ between 6 and $24 \mathrm{~h}$ were linear on semilogarithmic scale. The linear portions of the plasma disappearance curves on semilog scale were determined by a least squares analysis. The fractional disappearance rate $(k)$ is the slope, and the total distribution space (TDS) is the reciprocal of the 0 -time extrapolate, $100 / \%$ dose $/ \mathrm{ml}$. The metabolic clearance rate (MC) is the product of $k$ and TDS.

Hormonal binding by plasma proteins was assessed by simultaneous equilibrium dialysis of $\left[{ }^{131} \mathrm{I}\right] \mathrm{T}_{3}$ and $\left[{ }^{125} \mathrm{I}\right] \mathrm{T}_{4}$ in a diluted system (15). The dialyzable fraction (DF) is proportional to the original free hormone fraction in undiluted plasma. The overall strength of binding of undiluted plasma $\left(b_{P}\right)$ is defined by the expression (1-DF/DF) (150) as proposed by Oppenheimer, Schwartz, Shapiro, Bernstein, and Surks (11). The intrinsic cellular clearance or free hormone clearance, i.e., metabolic clearance corrected for differential hormonal binding by plasma proteins, was calculated as the product of the $\mathrm{MC}$ and the $\mathrm{b}_{\mathbf{P}}$ (11). Plasma binding determinations utilized in the calculation of the cellular clearances were performed on individual terminal plasma turnover specimens in triplicate. Plasma protein-bound iodine was measured in animals that were not injected with iodide.

Complete collections of urine and feces were obtained during the turnover study. Urinary collection funnels were washed with water, and the rinse was pooled with the urine. Fecal pellets were extracted from the colon postmortem and combined with the fecal collections. Feces were digested and homogenized in concentrated $\mathrm{KOH}$. Urinary and fecal clearances were calculated as the product of the $\mathrm{MC}$ and the fraction of excreted radioactivity in urine and feces. Recovery of the injected dose was calculated as the sum of the \% dose excreted in urine and feces and the retained radioactivity at $24 \mathrm{~h}$ (TDS [ml] $\times$ terminal plasma radioactivity concentration $[\%$ dose $/ \mathrm{ml}])$. At the termination of the turnover study, the liver was removed and weighed. The hepatic distribution space (HDS) was computed as the quotient of total hepatic radioactivity and the terminal plasma concentration of radioactivity.

The tissue binding of iodothyronines was measured 35 min after the intravenous administration of a predialyzed dose containing $1.25 \mu \mathrm{Ci}\left[{ }^{131} \mathrm{I}\right] \mathrm{T}_{3}$ and $2.5 \mu \mathrm{Ci}\left[{ }^{125} \mathrm{I}\right] \mathrm{T}_{4}$ in $1 \%$ HSA. During the 35 -min interval postinjection there is negligible metabolic transformation of isotopically labeled iodothyronines, and the observed activities in plasma and tissues reflect the presence of intact hormones (3). Tissue

\footnotetext{
s During the single exponential phase of plasma hormonal disappearance a constant fraction of plasma ${ }^{125} \mathrm{I}$ activity (93\%) was precipitable with TCA. In contrast, only $33 \%$ of the plasma ${ }^{151} \mathrm{I}$ activity was associated with the precipitated plasma proteins. Consonant with the findings of others (11) no significant accumulation of ethanol nonextractable iodine in plasma was detected during the $24 \mathrm{~h}$ after injection of labeled hormones. Hence, plasma iodothyronine activity was taken as the fraction of plasma radioactivity precipitable with TCA.
} 
TABLE I

Effect of Cold Acclimation on the Peripheral Metabolism of $T_{3}$ and $T_{4}$

\begin{tabular}{|c|c|c|c|c|c|c|}
\hline & \multicolumn{3}{|c|}{$T_{3}$} & \multicolumn{3}{|c|}{$\mathrm{T}_{4}$} \\
\hline & $C$ & $A$ & $P$ & $C$ & $A$ & $P$ \\
\hline Plasma Fractional Turnover (per $24 \mathrm{~h}$ ) & $2.22 \pm 0.03$ & $2.36 \pm 0.02$ & $<0.001$ & $1.17 \pm 0.04$ & $1.65 \pm 0.05$ & $<0.001$ \\
\hline Hormonal Distribution Space $(\mathrm{ml} / 100 \mathrm{~g})$ & $144 \pm 6.96$ & $191 \pm 7.97$ & $<0.001$ & $13.8 \pm 0.68^{*}$ & $16.5 \pm 0.66$ & $<0.01$ \\
\hline Metabolic Clearance $(\mathrm{ml} / 100 \mathrm{~g}$ per $24 \mathrm{~h})$ & $319 \pm 15$ & $452 \pm 20$ & $<0.001$ & $16.9 \pm 1.24$ & $27.4 \pm 1.57$ & $<0.001$ \\
\hline Urinary Clearance $(\mathrm{ml} / 100 \mathrm{~g}$ per $24 \mathrm{~h})$ & $197 \pm 14$ & $251 \pm 11$ & $<0.005$ & $7.93 \pm 0.85$ & $12.7 \pm 0.91$ & $<0.001$ \\
\hline Fecal Clearance $(\mathrm{ml} / 100 \mathrm{~g}$ per $24 \mathrm{~h})$ & $122 \pm 11$ & $201 \pm 15$ & $<0.001$ & $8.94 \pm 0.54$ & $14.7 \pm 0.82$ & $<0.001$ \\
\hline Cellular Clearance $(\mathrm{ml} / 100 \mathrm{~g}$ per $24 \mathrm{~h})$ & $27,513 \pm 3,364$ & $42,085 \pm 1,910$ & $<0.001$ & $8,714 \pm 1,279$ & $18,696 \pm 1,338$ & $<0.001$ \\
\hline Hepatic Distribution Space $(\mathrm{ml} / 100 \mathrm{~g})$ & $14.1 \pm 0.59$ & $15.6 \pm 0.45$ & $<0.05$ & $2.36 \pm 0.15$ & $3.37 \pm 0.15$ & $<0.001$ \\
\hline Plasma Binding (bP) & $78.0 \pm 5.46$ & $94.4 \pm 4.33$ & $<0.05$ & $495 \pm 61.5$ & $716 \pm 57.1$ & $<0.02$ \\
\hline Recovery (\% injected dose) & $65.3 \pm 3.02$ & $73.8 \pm 2.40$ & NS & $69.0 \pm 1.89$ & $70.1 \pm 1.74$ & NS \\
\hline
\end{tabular}

Hormonal turnover studies performed in 17 control $(C)$ and 19 cold-acclimated $(A)$ animals during a 24-h period after the simultaneous intravenous injection of $\left[{ }^{131} \mathrm{I}\right] \mathrm{T}_{3}$ and $\left[{ }^{125} \mathrm{I}\right] \mathrm{T}_{4}$. Data pooled from studies of animals adapted to cold for 13, 18, and 18 wk. Animal weight (mean $\pm \mathrm{SE}$ $[\mathrm{g}]): C, 587 \pm 18 ; A, 532 \pm 59(P=\mathrm{NS})$. Liver weight $(\mathrm{g}): C, 15.8 \pm 0.46 ; A, 18.1 \pm 0.54(P<0.001)$. Mean \pm SE. Statistical analyses performed using Student $t$ test.

* Series of 16 animals.

binding was defined in terms of tissue: plasma concentration ratios corrected for differential hormonal binding by plasma proteins determined experimentally by equilibrium dialysis (11). Tissue: plasma concentration ratios and plasma binding were determined individually in all animals studied.

The observed tissue concentrations of hormones were corrected for the presence of iodothyronines bound to plasma proteins sequestered in tissues. It was assumed that the diffusion space of plama proteins in tissue could be approximated by the measurement of the tissue diffusion space of albumin. Accordingly, the apparent tissue distribution volume of $\left.{ }^{[131} \mathrm{I}\right]$ albumin $35 \mathrm{~min}$ postinjection was determined in a group of eight animals. The albumin space was taken as the quotient of the \% dose/g in tissue and the $\%$ dose $/ \mathrm{ml}$ in plasma. The concentration of hormone in the cellular compartment of a given tissue was computed after correction of the observed tissue concentration for the hormonal activity associated with albumin. $35 \mathrm{~min}$ after the administration of the tracer preparations, the animals were exsanguinated, organs were excised and weighed, and weighed samples of tissues were digested in concentrated $\mathrm{KOH}$ and assayed for radioactivity. Plasma specimens were counted after the precipitation of plasma proteins with $20 \%$ TCA.

Biliary studies were performed $18 \mathrm{~h}$ after the intravenous injection of a combined dose of $15 \mu \mathrm{Ci}\left[{ }^{131} \mathrm{I}\right] \mathrm{T}_{3}$ and $5 \mu \mathrm{Ci}$ $\left[{ }^{125} \mathrm{I}_{\mathrm{T}} \mathrm{T}_{4}\right.$. The bile duct was cannulated under light ether anesthesia, and the freely flowing bile was collected during a 30-min period. Heparinized blood samples were obtained immediately before and at the termination of the collection. Plasma and bile specimens were precipitated with $20 \%$ TCA after the addition of outdated bank plasma. Bile: plasma iodothyronine ratios were calculated as the ratio of radioactivity in equal volumes of bile and plasma. The biliary clearance was taken as the quotient of the total radioactivity excreted in bile per hour and the mean plasma concentration of radioactivity.

The subcellular distribution of injected iodothyronines was determined $35 \mathrm{~min}$ after the intravenous administration of a predialyzed dose containing $\left[{ }^{131} \mathrm{I}^{1} \mathrm{~T}_{3}\right.$ and $\left[{ }^{125} \mathrm{I}\right] \mathrm{T}_{4} . A$ $3-g$ sample of liver was homogenized in 3.5 vol of $0.32 \mathrm{M}$ sucrose. Nuclear, mitochondrial, and microsomal fractions were obtained after differential centrifugation at $4^{\circ} \mathrm{C}$ at $750,9,000$, and $105,000 g(5)$. The final supernate obtained after ultracentrifugation, containing the soluble cytoplasmic fraction, was designated as the cytosol. Particulate fractions washed in $0.32 \mathrm{M}$ sucrose were dissolved in $0.75 \%$ desoxycholate before assay of radioactivity and protein concentrations. Proteins measurements were performed by the Biuret method. Recovery of the injected dose in the subcellular fractions was determined as the ratio of the aggregate subcellular radioactivity concentration (\% dose/ g) and the radioactivity concentration in separately measured whole-tissue specimens (\% dose/g).

Partial separation of the microsomal fraction into smooth (SER) and rough (RER) endoplasmic reticula was performed in a discontinuous sucrose gradient (5). After homogenization in $0.25 \mathrm{M}$ sucrose, nuclear and mitochondrial fractions were sedimented together at $9,000 \mathrm{~g}$. The supernate was layered over a dense sucrose solution (1.3 $\mathrm{M})$ and centrifuged for $90 \mathrm{~min}$ at $105,000 \mathrm{~g}$. The supernate was removed, and the intermediate layer (SER) was separated from the lower dense solution and pellet (RER). The protein concentrations of microsomal subfractions were measured by the method of Lowry, Rosebrough, Farr, and Randall (16).

\section{RESULTS}

Peripheral metabolism of iodothyronines (hormonal turnover, distribution, clearances, and binding by plasma proteins (Tables $I-I I I$ ). Iodothyronine turnover and metabolism were measured in three separate studies in animals acclimated to the cold for 13,18 , and $18 \mathrm{wk}$. Despite augmentation of hormonal binding by plasma protein in cold-adapted animals, alterations in kinetic parameters were comparable in each study, and the pooled results are summarized in Table I. After acclimation, the metabolic clearances of $T_{3}$ and $T_{4}$ increased 41.7 and $62.1 \%$, respectively, above levels in control animals. The increased metabolic clearances were due to increased disposition of the two hormones via both urinary deiodinative and fecal routes. Percent increases in the cold acclimated animals: $\mathrm{T}_{8}$, urinary clearance, $27.4 \%$, fecal clearance, $64.8 \% ; \mathrm{T}_{4}$, urinary clearance, $60.2 \%$, fecal 
TABLE II

Effect of Cold Acclimation on Biliary Excretion of Iodothyronines

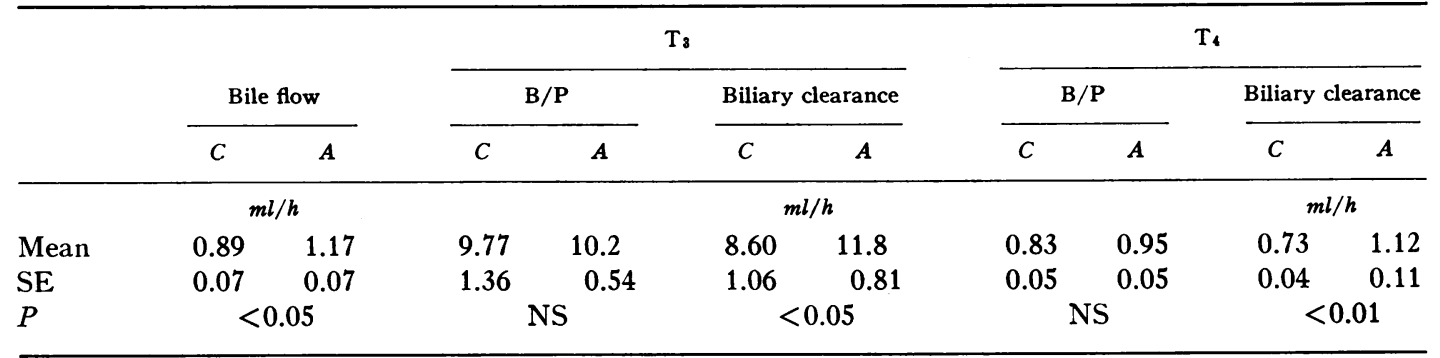

Biliary studies performed $18 \mathrm{~h}$ after administration of labeled thyroid hormones in five control $(C)$ and six animals adapted to the cold for $14 \mathrm{wk}(A) . \mathrm{B} / \mathrm{P}$, bile:plasma concentration ratio.

clearance, $64.4 \%$. The increased hormonal excretion in feces was accompanied by an approximately threefold increase in fecal output (mean $\pm \mathrm{SE}, \mathrm{g} / 24 \mathrm{~h}$ ) : control, $8.22 \pm 0.46$; cold-adapted, $23.7 \pm 1.13(P<0.001)$. Fractional disappearance rates from plasma were accelerated, and total distribution spaces were increased in the coldexposed group. Cellular clearances were elevated in these animals (experimental:control mean cellular clearance ratios: $\left.\mathrm{T}_{\mathbf{3}}, 1.53 ; \mathrm{T}_{4}, 2.15\right)$. The body retention of injected hormone at $24 \mathrm{~h}$ (\% dose) was significantly decreased in acclimated animals: $\mathrm{T}_{\mathrm{s}}$, control, $11.4 \pm 0.55$,

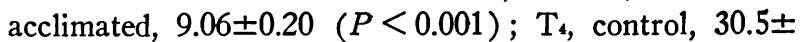
1.52 , acclimated, $18.4 \pm 0.84$. Significant enlargement of the hepatic distribution spaces of both hormones was detected in experimental animals (increases above control levels: $\mathrm{T}_{3}, 10.6 \%, \mathrm{~T}_{4}, 42.8 \%$ ). No significant differences were noted in the recovery of the injected dose in control and acclimated animals.

Despite the tendency towards retardation of weight gain displayed by the cold-exposed animals, increases were observed in relative liver weight and in one study in absolute liver weight (Table I). Enhanced hormonal removal through the biliary pathway was noted after acclimation (Table II). Increased bile flow and biliary clearances of $T_{8}$ and $T_{4}$ were noted in the adapted animals, while no change was detected in the bile: plasma iodothyronine ratios.

The binding of iodothyronines by plasma proteins was assessed by equilibrium dialysis (Table III). Considerable variation in plasma hormonal binding has been noted among control groups of different litters. Accordingly, littermates were divided into control and experimental groups and studied after the designated acclimation periods. After the acclimation periods used in these studies, namely, 12-21 wk, a tendency of augmented hormonal binding by plasma proteins was noted in the exposed animals. At 12-13 wk either no changes were observed, or small but not significant (Table IVV) increases in plasma binding were observed. Acclimation periods of 17-21 wk were associated with significant augmentation in plasma binding of the two hormones. Significant reductions in the plasma proteinbound iodine were observed after 13 and 21 wk at $4^{\circ} \mathrm{C}$ (Table III).

TABLE III

Effect of Cold Acclimation on the Plasma Protein-Bound Iodine Concentration and Plasma Binding of Iodothyronines

\begin{tabular}{|c|c|c|c|c|c|c|c|c|c|c|c|c|c|c|c|c|}
\hline & & & & & \multicolumn{12}{|c|}{ Dialyzable fractions } \\
\hline & \multicolumn{4}{|c|}{ PBI } & \multicolumn{6}{|c|}{$T_{3}$} & \multicolumn{6}{|c|}{$T_{4}$} \\
\hline & \multicolumn{2}{|c|}{$13 \mathrm{wk}$} & \multicolumn{2}{|c|}{$21 \mathrm{wk}$} & \multicolumn{2}{|c|}{$13 \mathrm{wk}$} & \multicolumn{2}{|c|}{$17 \mathrm{wk}$} & \multicolumn{2}{|c|}{$21 \mathrm{wk}$} & \multicolumn{2}{|c|}{$13 \mathrm{wk}$} & \multicolumn{2}{|c|}{$17 \mathrm{wk}$} & \multicolumn{2}{|c|}{$21 \mathrm{wk}$} \\
\hline & C & $A$ & C & $A$ & $C$ & $A$ & $C$ & $A$ & C & $A$ & $C$ & $A$ & $C$ & $A$ & $C$ & $\boldsymbol{A}$ \\
\hline & \multicolumn{2}{|c|}{$\mu \mathrm{g} / 100 \mathrm{ml}$} & \multicolumn{2}{|c|}{$\mu \mathrm{g} / 100 \mathrm{ml}$} & & & & & & & & & & & & \\
\hline Mean & 3.21 & 2.65 & 2.64 & 2.13 & 0.66 & 0.67 & 0.72 & 0.60 & 0.72 & 0.65 & 0.26 & 0.26 & 0.42 & 0.15 & 0.36 & 0.20 \\
\hline $\mathrm{SE}$ & 0.11 & 0.12 & 0.16 & 0.16 & 0.03 & 0.03 & 0.04 & 0.01 & 0.02 & 0.01 & 0.05 & 0.03 & 0.07 & 0.01 & 0.04 & 0.02 \\
\hline $\mathbf{n}$ & 14 & 14 & 11 & 11 & 6 & 5 & 6 & 6 & 11 & 10 & 6 & 5 & 6 & 6 & & 10 \\
\hline$P$ & \multicolumn{2}{|c|}{$<0.05$} & \multicolumn{2}{|c|}{$<0.05$} & \multicolumn{2}{|c|}{ NS } & \multicolumn{2}{|c|}{$<0.01$} & \multicolumn{2}{|c|}{$<0.05$} & \multicolumn{2}{|c|}{ NS } & \multicolumn{2}{|c|}{$<0.005$} & \multicolumn{2}{|c|}{$<0.005$} \\
\hline
\end{tabular}

The plasma protein-bound iodine concentration (PBI) was measured after 13 and 21 wk of exposure to cold. Dialyzable fractions of $T_{3}$ and $T_{4}$ measured by equilibrium dialysis. 
Analysis of the binding of iodothyronines by tissues (Tables $I V$ and $V$ ). When hormones are significantly bound to plasma proteins, their observed concentrations in tissues may be influenced in large measure by the presence of the plasma protein-hormone complex sequestered in the tissue vascular space. In order to assess the contribution of plasma-bound hormonal activity to the activity measured in a digested tissue specimen, the 35-min distribution space of albumin was assessed in diverse tissues. Since $T_{3}$ is approximately only onesixth as tightly bound to plasma proteins as $T_{4}$ and since the intrinsic cellular binding of $T_{3}$ by tissues exceeds that of $T_{4}$ by as much as fivefold, the magnitude of the contribution of plasma bound activity is greater in the case of $T_{4}$. The mean percent contribution of plasma activity to the observed $T_{3}$ activity in specific tissues was as follows: liver, kidney, and muscle, less than 2; spleen, 6 ; testis, 26 . The corresponding values for $T_{4}$ were: liver, 12; kidney, 32 ; and muscle, 45 . In the remaining organs, the large percent contribution of plasma $T_{4}$ activity precluded the accurate assessment of tissue concentrations of this hormone.

The binding of iodothyronines was defined in terms of in vivo tissue: plasma concentration ratios corrected for differential hormonal binding by plasma proteins. The binding of individual plasma specimens was analyzed in triplicate by equilibrium dialysis. In the series

TABLE IV

Effect of Cold Acclimation on the Binding of $T_{3}$ by Tissues

\begin{tabular}{|c|c|c|c|}
\hline & Control & Acclimated & $P$ \\
\hline \multicolumn{4}{|c|}{$\begin{array}{l}\text { Tissue: plasma } \\
\text { concentration ratio }\end{array}$} \\
\hline $\mathrm{L} / \mathrm{P}$ & $4.97 \pm 0.36$ & $6.90 \pm 0.41$ & $<0.005$ \\
\hline $\mathrm{K} / \mathrm{P}$ & $6.98 \pm 0.30^{*}$ & $8.98 \pm 0.50$ & $<0.005$ \\
\hline $\mathrm{S} / \mathrm{P}$ & $1.12 \pm 0.08$ & $1.37 \pm 0.08$ & $<0.05$ \\
\hline $\mathrm{T} / \mathrm{P}$ & $0.08 \pm 0.005$ & $0.11 \pm 0.013$ & $<0.05$ \\
\hline $\mathrm{M} / \mathrm{P}$ & $0.29 \pm 0.01$ & $0.35 \pm 0.03$ & $<0.05$ \\
\hline \multicolumn{4}{|c|}{ Plasma binding } \\
\hline$b_{P}$ & $157 \pm 8$ & $164 \pm 7$ & NS \\
\hline \multicolumn{4}{|c|}{ Tissue binding } \\
\hline $\mathrm{b}_{\mathrm{L}}$ & $788 \pm 77$ & $1,123 \pm 72$ & $<0.005$ \\
\hline $\mathrm{b}_{\mathrm{K}}$ & $1,079 \pm 64^{*}$ & $1,465 \pm 95$ & $<0.005$ \\
\hline $\mathrm{bs}_{\mathrm{s}}$ & $176 \pm 16$ & $222 \pm 13$ & $<0.05$ \\
\hline $\mathrm{b}_{\mathrm{T}}$ & $11.8 \pm 1.0$ & $17.0 \pm 1.9$ & $<0.05$ \\
\hline $\mathrm{b}_{\mathrm{M}}$ & $45.3 \pm 3.3$ & $56.3 \pm 4.0$ & $<0.05$ \\
\hline
\end{tabular}

Analysis of tissue binding was performed $35 \mathrm{~min}$ after the administration of a combined dose of $\left[{ }^{131} \mathrm{I}\right] \mathrm{T}_{3}$ and $\left[{ }^{125} \mathrm{I}\right] \mathrm{T}_{4}$ in 14 control and 14 animals acclimated for $12 \mathrm{wk}$. bP, overall plasma binding, hormonal binding by liver, kidney, spleen, testis, and muscle are denoted respectively: $b_{\mathrm{L}}, \mathrm{b}_{\mathrm{K}}, \mathrm{b}_{\mathrm{S}}, \mathrm{b}_{\mathrm{T}}$, and $\mathrm{b}_{\mathrm{M}}$. Mean \pm SE.

* Series of 13 observations.

\section{TABLE V \\ Effect of Cold Acclimation of the Binding of $T_{4}$ by Tissues}

\begin{tabular}{|c|c|c|c|}
\hline & Control & Acclimated & $P$ \\
\hline \multicolumn{4}{|c|}{$\begin{array}{l}\text { Tissue: plasma } \\
\text { concentration ratio }\end{array}$} \\
\hline $\mathrm{L} / \mathrm{P}$ & $0.57 \pm 0.04$ & $0.81 \pm 0.08$ & $<0.01$ \\
\hline $\mathrm{K} / \mathrm{P}$ & $0.27 \pm 0.02^{*}$ & $0.37 \pm 0.03$ & $<0.01$ \\
\hline $\mathrm{M} / \mathrm{P}$ & $0.010 \pm 0.001$ & $0.014 \pm 0.002$ & $0.1-0.05$ \\
\hline \multicolumn{4}{|c|}{ Plasma binding } \\
\hline $\mathrm{b}_{\mathrm{P}}$ & $977 \pm 78$ & $1,072 \pm 67$ & NS \\
\hline \multicolumn{4}{|c|}{ Tissue binding } \\
\hline $\mathrm{b}_{\mathrm{L}}$ & $546 \pm 49$ & $853 \pm 90$ & $<0.01$ \\
\hline $\mathrm{b}_{\mathrm{K}}$ & $254 \pm 21^{*}$ & $390 \pm 34$ & $<0.005$ \\
\hline $\mathrm{b}_{\mathrm{M}}$ & $10.1 \pm 1.25$ & $14.5 \pm 1.66$ & $<0.05$ \\
\hline
\end{tabular}

Tissue binding of $\left[{ }^{125} \mathrm{I}\right] \mathrm{T}_{4}$ analyzed in animals studied in Table IV. Mean \pm SE.

* Series of 13 observations.

of animals in which the tissue binding of iodothyronines was assessed after $12 \mathrm{wk}$ of exposure to $4^{\circ} \mathrm{C}$, no significant differential hormonal binding by plasma proteins was detected. Thus, the tissue binding of the hormones was reflected in the observed tissue: plasma ratios. The tissue: plasma ratios of $T_{s}$ were uniformly elevated in the cold-adapted group (Table IV). Increments of similar magnitude in the tissue binding of $\mathrm{T}_{3}$ were noted after cold acclimation: liver, $40 \%$; kidney, $40 \%$; spleen, $30 \%$; testis, $40 \%$; and muscle, $30 \%$. The tissue: plasma ratios of $\mathrm{T}_{4}$ were similarly elevated after adaptation (Table V). Although the increase in the muscle: plasma $\mathrm{T}_{4}$ ratio did not achieve the 0.05 significance level, the muscle binding of this hormone was significantly increased. Liver and kidney binding of $T_{4}$ were similarly augmented in the exposed group. Increments noted in specific tissues: liver, $60 \%$; kidney, $50 \%$; and muscle, $40 \%$. Consonant with the results of earlier studies of the effects of cold acclimation on organ weight by Hale, Mefferd, Vawter, Foerster, and Criscuolo (17), attendant significant increases in relative organ weights were noted in the case of liver, kidney, and testis but not of spleen.

The data obtained permit a comparison of the relative net strength of binding of iodothyronines in liver, kidney, and muscle. The ratio of $\mathrm{T}_{3}: \mathrm{T}_{4}$ tissue binding in the control animals was: liver, 1.44 ; kidney, 4.25 ; and muscle, 4.49. The corresponding ratio in tissues of acclimated animals was: liver, 1.32; kidney, 3.76; and muscle, 3.88 . The relatively greater binding by extrahepatic tissues of $T_{3}$ compared to $T_{4}$ is in keeping with the observed differences in the distribution of these hormones. 
TABLE VI

Effect of Cold Acclimation on the Hepatic Subcellular Distribution

of Injected Tracer Iodothyronines

\begin{tabular}{|c|c|c|c|c|c|c|}
\hline & \multirow[b]{2}{*}{$\mathrm{L} / \mathrm{P}$} & \multirow[b]{2}{*}{ bL } & \multicolumn{4}{|c|}{$\%$ Iodothyronines in } \\
\hline & & & Nuclei & Mitochondria & Microsomes & Cytosol \\
\hline \multicolumn{7}{|l|}{$\mathrm{T}_{3}$} \\
\hline Control & $7.80 \pm 0.23$ & $416 \pm 37$ & $42.1 \pm 1.83$ & $8.43 \pm 0.85$ & $25.8 \pm 1.10$ & $23.5 \pm 1.74$ \\
\hline $\begin{array}{l}\text { Cold-acclimated } \\
P\end{array}$ & $\begin{array}{c}8.41 \pm 0.56 \\
\text { NS }\end{array}$ & $\begin{array}{l}681 \pm 78 \\
<0.01\end{array}$ & $\begin{array}{c}39.7 \pm 1.53 \\
\text { NS }\end{array}$ & $\begin{array}{c}8.39 \pm 0.49 \\
\text { NS }\end{array}$ & $\begin{array}{c}29.9 \pm 1.14 \\
<0.02\end{array}$ & $\begin{array}{c}22.1 \pm 1.52 \\
\text { NS }\end{array}$ \\
\hline \multicolumn{7}{|l|}{$\mathrm{T}_{4}$} \\
\hline Control & $0.69 \pm 0.02$ & $201 \pm 36$ & $37.3 \pm 2.05$ & $10.6 \pm 1.0$ & $32.7 \pm 1.51$ & $19.4 \pm 1.23$ \\
\hline Cold-acclimated & $0.84 \pm 0.04$ & $612 \pm 79$ & $34.6 \pm 1.11$ & $10.5 \pm 0.94$ & $39.2 \pm 0.94$ & $15.7 \pm 0.83$ \\
\hline$P$ & $<0.005$ & $<0.001$ & . $\quad \mathrm{NS}$ & NS & $<0.005$ & $<0.05$ \\
\hline
\end{tabular}

11 control and 9 animals acclimated to cold for $21 \mathrm{wk}$ were studied $35 \mathrm{~min}$ after the intravenous administration of a combined dose of $\left[{ }^{131} \mathrm{I}\right] \mathrm{T}_{3}$ and $\left[{ }^{125} \mathrm{I}\right] \mathrm{T}_{4}$. $\mathrm{L} / \mathrm{P}$, liver:plasma radioactivity concentration ratio; $\mathrm{b}_{\mathrm{L}}$, hepatocellular binding. Recovery of tracer-labeled hormones in subcellular fractions $(\%)$ : $\mathrm{T}_{3}$, control, 84.1 \pm 2.48 , accli-

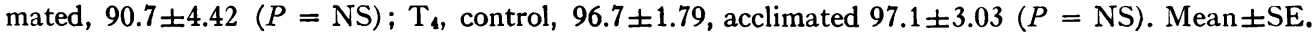

Subcellular partition of iodothyronines (Table VI). The study of the hepatic subcellular distribution of thyroid hormones was combined with the simultaneous evaluation of whole tissue: plasma concentration ratios and with the assessment of hepatocellular binding. The subcellular concomitant of the observed increase in hepatocellular binding was increased binding by the microsomal fraction. No significant differences were noted in the percent of labeled iodothyronines associated with nuclear, mitochondrial, or cytosol fractions. Recovery of the dose in subcellular fractions was similar in control and acclimated animals. Analysis of the distribution of subcellular proteins disclosed a concordant increase in the protein content of the microsomal membranes. Microsomal subfractionation revealed significant increase of the smooth membranous component but no detectable alteration in the granular component. The protein concentrations of the microsomal subfractions were measured in a series of nine control and nine coldadapted animals (mean $\pm \mathrm{SE}, \mathrm{mg}$ protein/g liver) : RER, control, $22.4 \pm 0.74$, experimental, $21.58 \pm 0.58(P=\mathrm{NS})$ : SER, control 20.8 \pm 1.39 , experimental $28.2 \pm 1.39(P<$ $0.005)$.

\section{DISCUSSION}

The increased peripheral metabolism of thyroid hormones observed after acclimation to cold was associated with widespread stimulation of hormonal binding by tissues. Analysis of the subcellular distribution of the increased liver binding noted after adaptation disclosed enhancement of the binding of iodothyronines by microsomal membranes. The increased metabolism was due to augmentation of cellular hormonal turnover. Resolution of the plasma protein and cellular determinants of the cold-induced increases in metabolic clearances revealed elevated cellular clearances of the two hormones. Hormonal binding by plasma proteins was either unchanged or augmented depending on the length of exposure to the cold.

Consonant with earlier observations, increased relative hepatic weight was noted in the presence of growth retardation after cold adaptation (17). The increased relative liver weight was associated with an enlarged hepatic space of $T_{4}$ and, to a lesser degree, of $T_{\mathbf{z}}$. Moreover, the increased TDS of $T_{4}$ appeared explained largely by the observed expansion of the hepatic space of this hormone. In contrast, the enlarged TDS of $\mathrm{T}_{8}$ appeared to be predominantly of extrahepatic origin since only a small increase was detected in the hepatic space of this iodothyronine. Hepatocellular binding of both hormones was stimulated as a result of exposure to the cold. The subcellular accompaniment of the increased hepatocellular binding of iodothyronines was increased hormonal binding by the hepatic microsomal fraction. The importance of microsomal binding of $T_{\text {s }}$ as a determinant of overall hepatocellular binding of this hormone has been emphasized in previous studies (11). The present investigations demonstrate additionally that microsomal binding of $\mathrm{T}_{\mathbf{8}}$ can influence the liver binding of this iodothyronine. Moreover, although a smaller fraction of the intracellular $T_{\mathbf{s}}$ pool was bound to microsomes, the overall hepatocellular binding of this hormone exceeded that of $T_{4}$ in two separate studies.

The increased hepatic metabolism of thyroid hormones may be related to the increase of hepatic membrane-bound intracellular enzymes associated with the metabolism of iodothyronines. Since iodothyronine deiodinase and the enzymes involved in the metabolic trans- 
formation of the hormones before biliary excretion are associated with the hepatic microsomal fraction (6-9, 18 ), it appears likely that the increased microsomal binding of iodothyronines observed after cold acclimation was associated with enhanced activity of these enzymes as a result of the cold. Furthermore, the demonstration in the current studies of stimulation of the enzymeladen smooth component of hepatic microsomes after acclimation is in keeping with this notion. The increased protein concentration of the SER demonstrated after exposure suggests further the possibility of stimulation of additional microsomal constituents such as the drug metabolizing enzymes.

The finding of increased hormonal binding by extrahepatic tissues after cold exposure suggests the possibility of induction of tissue deiodinative sites by the cold stimulus. Previous investigations have suggested that hormonal deiodination in tissues is proportional to the concentration of exchangeable hormone (10). The suggestion that increased tissue binding is related to enhanced tissue deiodination, as appears to be true in the case of the liver, would be consonant with significant differences observed in the drug-induced stimulation of iodothyronine metabolism and that mediated by the cold. The effect of phenobarbital administration appears restricted to the stimulation of degradative sites within the liver, since drug induction does not enhance extrahepatic binding of thyroid hormones (11). Moreover, phenobarbital induction is associated with the enhancement of the deiodinative clearance and TDS of $T_{4}$ but not of $T_{s}$ (11). This evidence of differential stimulation of iodothyronine metabolism appears consistent with the notion of the preeminence of extrahepatic tissues in the deiodination of $T_{\mathbf{s}}$. Thus, stimulation of hepatic deiodinative sites exclusively would be expected to effect slight change in overall deiodination of $\mathrm{T}_{3}$. Indeed, small changes in the deiodinative clearance and TDS of this hormone related to enhancement of hepatic metabolism would, presumably, be extremely difficult to detect. In the present studies, in contrast, the deiodinative disposition, TDS, and extrahepatic binding of $\mathrm{T}_{3}$ as well as $T_{4}$ were increased after acclimation, findings which suggest the participation of extrahepatic deiodinative sites in the cold-induced stimulation of hormonal metabolism.

Previous studies have documented increased metabolism of $T_{4}$ after cold exposure $(12-14,19)$. Intoccia and Van Middlesworth demonstrated increased fecal disposition of $\mathrm{T}_{4}$ in rats exposed to $10^{\circ} \mathrm{C}$ for approximately 2 wk (20). Cottle noted that increased fecal hormonal clearance was associated with increased biliary clearance (21). Cold stimulation of the deiodinative disposition of thyroid hormones observed in the present studies is in keeping with the observations of Albright, Heninger, and Larson (22) and Hillier (23). In contrast, Galton and Nisula detected a reduction in the deiodinative clear- ance of thyroxine in cold-adapted rats after isotopic equilibration with injected radiothyroxine (13). A decreased concentration of serum protein-bound iodine after long-term adaptation has been observed in earlier studies $(19,24)$. The depression of the plasma protein-bound iodine and the augmented hormonal binding by plasma proteins after acclimation noted in the current study are of uncertain etiology. Possible explanations of the reduction in the level of plasma hormonal iodine include inhibition of negative feedback stimulation of thyroid hormone secretion, preferential secretion by the thyroid gland of $T_{3}$ compared to $T_{4}$, and enhanced peripheral conversion of $T_{4}$ to $T_{3}$.

In conclusion, the present series of studies have demonstrated that the cold-induced stimulation of the metabolism of iodothyronines is associated with increased binding of these hormones by diverse tissues. The increased hepatic metabolism is associated with the augmentation of microsomal binding of both hormones and generalized stimulation of the SER. The stimulation of extrahepatic hormonal binding by cold suggests the existence of inducible binding sites of iodothyronines in extrahepatic tissues. The location and nature of these extrahepatic binding sites and their possible significance in the extrathyroidal conversion of $T_{4}$ to $T_{s}$ appear amenable to further experimental delineation.

\section{ACKNOWLEDGMENTS}

The author wishes to express his gratitude to the USAF School of Aerospace Medicine for its sponsorship of these investigations. Helpful discussion with Drs. Jack H. Oppenheimer and Harold L. Schwartz are gratefully acknowledged. Dr. James D. Lueck is cited for assistance rendered in the biliary studies, and Mr. Alton J. Rahe of the Biometrics Division of the School of Aerospace Medicine is cited for statistical consultation. Expert secretarial assistance was provided by Mrs. Mary L. Coen, Miss Josie M. Smith, and Mrs. Vickie A. Purdy.

\section{REFER ENCES}

1. Heninger, R. W., F. C. Larson, and E. C. Albright. 1963. Iodine-containing compounds of extrathyroidal tissues. J. Clin. Invest. 42: 1761.

2. Gorman, C. A., E. V. Flock, C. A. Owen, Jr., and J. Paris. 1966. Factors affecting exchange of thyroid hormones between liver and blood. Endocrinology. 79: 391.

3. Hasen, J., G. Bernstein, E. Volpert, and J. H. Oppenheimer. 1968. Analysis of the rapid interchange of thyroxine between plasma and liver and plasma and kidney in the intact rat. Endocrinology. 82: 37.

4. Tata, J. R., L. Ernster, and E. M. Suranyi. 1962. Interaction between thyroid hormones and cellular constituents. II. Intracellular distribution and the cell-sap effect. Biochim. Biophys. Acta. 60: 480.

5. Schwartz, H. L., G. Bernstein, and J. H. Oppenheimer. 1969. Effect of phenobarbital administration on the subcellular distribution of ${ }^{125} \mathrm{I}$-thyronine in rat liver: Importance of microsomal binding. Endocrinology. 84: 270.

6. Stanbury, J. B., M. L. Morris, H. J. Corrigan, and 
W. E. Lassiter. 1960. Thyroxine deiodination by a microsomal preparation requiring $\mathrm{FE}^{++}$, oxygen, and cysteines or glutathione. Endocrinology. 67: 353.

7. Wynn, J., R. Gibbs, and B. Royster. 1962. Thyroxine degradation. I. Study of optimal reaction conditions of a rat liver thyroxine-degrading system. J. Biol. Chem. 2.37: 1892.

8. Nakagawa, S., and W. R. Ruegamer. 1967. Properties of a rat tissue iodothyronine deiodinase and its natural inhibitor. Biochemistry. 6: 1249.

9. Schwartz, H. L., V. Kozyreff, M. I. Surks, and J. H. Oppenheimer. 1969. Increased deiodination of $\mathrm{L}$-thyroxine and $\mathrm{L}$-triiodothyronine by liver microsomes from rat treated with phenobarbital. Nature (Lond.). 221: 1262.

10. Oppenheimer, J. H., G. Bernstein, and M. I. Surks. 1968. Increased thyroxine turnover and thyroidal function after stimulation of hepatocellular binding of thyroxine by phenobarbital. J. Clin. Invest. 47: 1399.

11. Oppenheimer, J. H., H. L. Schwartz, H. C. Shapiro, G. Bernstein, and M. I. Surks. 1970. Differences in primary cellular factors influencing the metabolism and distribution of 3,5,3'-L-triiodothyronine and L-thyroxine. J. Clin. Invest. 49: 1016.

12. Gregerman, R. I. 1963. Estimation of thyroxine secretion rate in the rat by radioactive thyroxine turnover technique: influence of age, sex, and exposure to cold. Endocrinology. $72: 382$.

13. Galton, V. A., and B. C. Nisula. 1969. Thyroxine metabolism and thyroid function in the cold-adapted rat. Endocrinology. 85: 79.

14. Cottle, M., and L. D. Carlson. 1956. Turnover of thyroid hormone in cold-exposed rats determined by radioactive iodine studies. Endocrinology. 59: 1.
15. Oppenheimer, J. H., R. Squef, M. I. Surks, and H. Hauer. 1963. Binding of thyroxine by serum proteins evaluated by equilibrium dialysis and electrophoretic techniques. Alterations in nonthyroidal illness. J. Clin. Invest. 42 : 1769.

16. Lowry, O. H., N. J. Rosebrough, A. L. Farr, and R. J. Randall. 1951. Protein measurement with the folin phenol reagent. J. Biol. Chem. 193: 265.

17. Hale, H. B., R. B. Mefferd, Jr., G. Vawter, G. F. Foerster, D. Criscuolo. 1959. Influence of long-term exposure to adverse environments on organ weights and histology. Am. J. Physiol. 196: 520.

18. Isselbacher, K. J. 1956. Enzymatic mechanisms of hormone metabolism II. Mechanism of hormonal glucuronide formation. Recent Prog. Horm. Res. 12: 134.

19. Heroux, O., and M. M. Petrovic. 1969. Effect of highand low-bulk diets on the thyroxine turnover rate in rats with acute and chronic exposure to different temperatures. Can. J. Physiol. Pharmacol. 47: 963.

20. Intoccia, A., and L. Van Middlesworth. 1959. Thyroxine excretion increase by cold exposure. Endocrinology. 64 : 462.

21. Cottle, W. H. 1964. Biliary and fecal clearance of endogenous thyroid hormone in cold-acclimated rats. $\mathrm{Am}$. J. Physiol. 207 : 1063.

22. Albright, E. C., R. W. Heninger, and F. C. Larson. 1965. Effect of cold-induced hyperthyroidism on iodinecontaining compounds of extrathyroid tissues. Curr. Top. Thyroid Res. Proc. Int. Thyroid Conf. 5: 346.

23. Hillier, A. P. 1968. Thyroxine deiodination during cold exposure in the rat. J. Physiol. (Lond.). 197: 135.

24. Ershoff, B. H., and O. J. Colub. 1950. Effects of prolonged exposure to cold on the serum protein-bound iodine of the rat. Arch. Biochem. 30: 202. 